\title{
CURRENT STATE AND DEVELOPMENT PROSPECTS OF THE RUSSIAN ECONOMY
}

\author{
IRINA RODIONOVA \\ Peoples' Friendship University of Russia, Faculty of Economics, \\ Department of Regional Economy and Geography, Moscow \\ TATIANA KOKUYTSEVA \\ Peoples' Friendship University of Russia, Faculty of Economics, Moscow
}

Manuscript received April 16, 2010

Revised version March 29, 2011

Rodionova I., KoKUYTSEva T., Current state and development prospects of the Russian economy. Quaestiones Geographicae 30(2), Bogucki Wydawnictwo Naukowe, Poznań 2011, pp. 23-34, 10 tables. DOI 10.2478/v10117011-0015-z, ISBN 978-83-62662-62-3, ISSN 0137-477X.

АвSTRACT: The article characterises changes that have occurred in the economy of Russia and its foreign trade over the recent years. It estimates the country's position in the world ranking. The process of Russia's involvement in integrated world economic development after the collapse of the socialist system has been far from simple, because it was simultaneous with the country's system transformation and economic restructuring. The economy of modern Russia operates in difficult conditions. In the 20th century the burden of the socialist period of the country's development combined with the mistakes of the structural economic transformation of the 1990s already generated new systemic disproportions which have greatly modified the entire economic complex of the country.

An analysis of the Russian share in the production of principal types of industrial products over the last three decades as well as a comparison of particular development indicators of the largest world economies and the share of countries and country groups in the world's high technology production reveals a weakening of the Russian position in the world economy. The article also presents changes in Russia's foreign trade and the decrease in its main economic indicators in the conditions of the current world financial crisis.

The article underlines the necessity of change in the current model of Russian participation in the globalising world towards a search for a new place in the world economy and the world market, and, first of all, in knowledge-intensive industries and the sphere of high technology.

KEY WORDS: Russia, economy, development, structural shifts, manufacturing industry, foreign trade, high-technology production

Irina Rodionova, Department of Regional Economy and Geography, Faculty of Economics, Peoples' Friendship University of Russia, Moscow, Miklukho-Maklaya str., 6, 117198, Moscow, Russia; e-mail: iarodionova@mail.ru

Tatiana Kokuytseva, Faculty of Economics, Peoples' Friendship University of Russia, Moscow, Miklukho-Maklaya str., 6, 117198, Moscow, Russia; e-mail: tk-snejinka@mail.ru 


\section{Current state of Russia's economy}

One of the surveys of the International Monetary Fund (IMF), Prospects of the development of the world economy: Crisis and recovery, claims that nowadays the world economy endures the deepest recession over the last 50 years. At the same time it notes that Russia and other countries of the Commonwealth of Independent States (CIS) have suffered the most in comparison with other countries from the global financial and economic crisis (World economic outlook ... 2009). IMF experts also state that the economies of Russia and the other CIS countries have borne great losses as a result of three major shocks: "the financial turbulence, which has greatly curtailed access to external funding; slumping demand from advanced economies; and the related fall in commodity prices, notably for energy". The strong direct influence of the financial turmoil on the CIS economies reflects a sharp outflow of foreign funding from their largest non-financial firms and, what is more important, from their bank systems.

As the authors of the scientific report Strategic directions of the economic development of Russia state, "the global financial and economic crisis has substantially depreciated all previous forecasts and programmes of development of the Russian economy, having divided the conditions of the economy's operation into «before», "during" and «after» it" (Strategic directions ... 2010: 7). Thus it is necessary to remember that the economy of present-day Russia functions in conditions when effective market mechanisms have not been fully formed yet, and the burden of the socialist period of development in combination with errors of the 1990s has already generated new systemic disproportions which have greatly transformed the country's entire economic complex. In other words, it is worth investigating the changes that have occurred during the last years, revealing structural shifts in the economy and, first of all, in the industry of Russia, and also estimating its position among other countries.

Let us consider the economic indicators characterising the current state of the economy of the Russian Federation. According to the International Monetary Fund, in 2008 its nominal gross domestic product (GDP) was 1.68 trillion
US dollars (the eighth place among the largest economies of the world), and following the developments of 2009 it decreased to $\$ 1.25$ trillion (1 $1^{\text {th }}$ place). In 2009 its growth rates were negative $(-7.5 \%)$ while at purchasing power parity (PPP) it was estimated at $\$ 2.1$ trillion $-8^{\text {th }}$ place (by comparison: in the USA - $\$ 14.3$ trillion, China $-\$ 8.8$ trillion, Japan $-\$ 4.1$ trillion). GDP per capita at PPP in Russia also dropped in 2009 in comparison with the previous year by 600 dollars (15,200 and 15,800 dollars, respectively). By comparison: GDP per capita at PPP in the USA - 46,400 dollars; in Japan - 32,600 dollars (The World Factbook).

It is also necessary to give the following data. In terms of the Index of Economic Freedom, in 2008 Russia was in the $134^{\text {th }}$ place out of 157 , and in 2010 - in the $143^{\text {rd }}$ place out of 183 (the data of this number of countries were analysed) (Index of Economic Freedom 2010). In the World Bank's Ease of Doing Business ranking, Russia dropped from 79th to 120th place out of 181 (2009) during the last years. In the World Bank ranking on the Knowledge Economy Index, which shows how countries succeed in putting inventions of scientists and engineers into practice, Russia occupies 41 st place out of 128 .

Thus, there seems to be a tendency for the basic economic indicators of Russia's development to decrease in the conditions of the current world financial and economic crisis. A sharp deterioration in the external economic conditions, a drop in exports, capital outflow, and the suspension of bank credit have led to a considerable reduction in investment activity and recession in industry. The decline in Russia's GDP in the first half of 2009, compared with the corresponding period of 2008 , was $10.4 \%$. By mid-2009 the economic recession had stopped and since June 2009 GDP was observed to start growing (On the results ... 2010). According to many analysts, the financial crisis and recession of 2008-2009 in Russia as part of the world financial crisis was possible because of the integration of the Russian economy into the world economy, as the prospects of development of the country cannot be estimated in isolation from the development and profound changes occurring in the world.

As experts of the Ministry of Economic Development and Trade of the Russian Federation 
point out, the decrease in the Russian GDP in 2009 was closely connected with a collapse in investment demand. Investments in fixed capital were reduced by $17 \%$, the decline in construction works was $16 \%$, while industrial production dropped by $10.8 \%$ compared with the 2008 level. The latter was mainly connected with a drop in manufacturing (by 16\%). The crisis in those branches greatly contributed to a slump in industrial production: the manufacture of transport vehicles and equipment (down from 2008 by $38 \%$ ), of electric, electronic and optical equipment (by $31.6 \%$ ), and of machines and equipment (by $28.4 \%$ ). The Russian export of goods was estimated in 2009 at $\$ 303.3$ billion, having dropped as a result of the fall of prices for raw materials at the beginning of the year. However, since April, export rates had positive growth dynamics caused basically by a restoration of growth of the oil price (up from about $\$ 43.5$ per barrel in the 1st quarter of 2009 to $\$ 74.1$ in the 4 th quarter). The import of goods to the Russian Federation was estimated at $\$ 192.7$ billion, having decreased in comparison with 2008 by $34.0 \%$ (On the results ... 2010).

The sharp drop in the world prices of goods constituting traditional Russian exports and the decrease in the availability of cheap credit at the end of 2008 and the beginning of 2009 provoked a collapse on the Russian stock market, rouble devaluation, a decrease in the industrial output, the gross domestic product and population incomes, as well as unemployment growth. Antirecession measures of the government required the expenditure of a considerable share of international reserves. As of July $1^{\text {st }}$, 2009, the international reserves of the Central Bank of Russia (earlier - gold and foreign currency) were $\$ 412,6$ billion (in comparison with July $1^{\text {st }}, 2008$, when the volume of the reserves was $\$ 569$ billion, this indicator decreased by $27.5 \%$ ). As of January $1^{\text {st }}$, 2010 the international reserves of the Central Bank were $\$ 440.6$ billion ${ }^{1}$.

International reserves are first-grade financial assets at the disposal of the Central Bank and the Government of the Russian Federation as of the reporting date. They consist of foreign currency, monetary gold, special drawing rights (SDR), the reserve position in the IMF, and other reserve assets. Data of the Central Bank of the Russian Federation (http:/ / cbr.ru).
On the whole, according to the forecasts of the Ministry of Economic Development and Trade of the Russian Federation, the World Bank and the International Monetary Fund, a reduction in Russia's GDP by 6-8\% expected for 2009 indeed occurred. The Ministry had to reconsider GDP growth for 2010-2012. Two scenarios of development were prepared. In the optimistic version, Russia's GDP in 2010 would grow by $0.5 \%$ (instead of the 3-4\% planned earlier). In 2011 the growth of the economy would be approximately $3 \%$, and in 2012 - more than $4 \%$. The pessimistic scenario provided for a GDP reduction by $0.9 \%$ in 2010, with economic growth supposed to begin only in 2011. It should be noted that the decrease in Russia's GDP was caused by the global financial and economic crisis and a sharp fall in demand for the main export goods of the country, but internal factors also had an influence, in particular such factor as an insufficient diversification of the economy (On the results ... 2010).

\section{Weakening of the position of Russia in the world economy}

As we know, the process of involving Russia in global economic development after the socialist system collapse has turned out to be far from simple, as it took place simultaneously with the system transformation and structural reorganisation of the whole economic complex of the country.

Let us look at the recent history. The collapse of the USSR and economic disintegration throughout the post-Soviet territory certainly had a very essential impact on weakening the state's position in the world economy at the end of the 20th century and the beginning of the 21 st. At the start of economic reforms, during the economic reorganisation 'from the plan to the market' of the 1990s, Russia, like the majority of the former communist coalition (nowadays countries with transition economies), was at an industrial stage of development. It should be stressed that throughout the second half of the 20th century the Soviet Union was not simply among the world leaders, but frequently occupied the $1^{\text {st }}-2^{\text {nd }}$ place in world rankings by many economic indicators, including growth rates of the output of many industries (Table 1). 
Table 1. Positions of the USSR and the USA in the world production of some goods in 1960-1990.

\begin{tabular}{|l|c|c|c|c|c|c|c|c|}
\hline \multirow{2}{*}{ Product } & \multicolumn{9}{|c|}{ USSR's position } & \multicolumn{4}{c|}{ USA's position } \\
\cline { 2 - 9 } & $\mathbf{1 9 6 0}$ & $\mathbf{1 9 7 0}$ & $\mathbf{1 9 8 0}$ & $\mathbf{1 9 9 0}$ & $\mathbf{1 9 6 0}$ & $\mathbf{1 9 7 0}$ & $\mathbf{1 9 8 0}$ & $\mathbf{1 9 9 0}$ \\
\hline Energy & 2 & 2 & 2 & 2 & 1 & 1 & 1 & 1 \\
\hline Oil & 3 & 2 & 1 & 1 & 1 & 1 & 3 & 2 \\
\hline Gas & 2 & 2 & 2 & 1 & 1 & 1 & 1 & 2 \\
\hline Coal & 3 & 2 & 3 & 3 & 2 & 1 & 1 & 2 \\
\hline Pig iron & 2 & 1 & 1 & 1 & 1 & 2 & 3 & 4 \\
\hline Steel & 2 & 2 & 1 & 1 & 1 & 1 & 3 & 3 \\
\hline Mineral fertilisers & 3 & 2 & 1 & 1 & 1 & 1 & 2 & 2 \\
\hline Chemical fibres & 5 & 4 & 3 & 5 & 1 & 1 & 1 & 1 \\
\hline Cement & 2 & 1 & 1 & 2 & 1 & 2 & 4 & 4 \\
\hline Paper & 5 & 5 & 3 & 6 & 1 & 1 & 1 & 1 \\
\hline Woollen cloth & 1 & 1 & 1 & 1 & 2 & 4 & 6 & 6 \\
\hline
\end{tabular}

Source: calculated by the authors.

As Treyvish notes in his works, "the economic history of the USSR was first of all the history of its industrialisation. The Soviet country developed industry as a guarantee of survival, with all its might, whatever the cost. The results are both, impressive and deplorable. Having turned into an industrial giant, the USSR did not catch up with the world economic leaders that were already postindustrial. And the Russia of today - the Russian Federation - having inherited 60\% of the economic potential of the USSR, has actually turned out to be a power and raw-material appendage of old and new leaders of the world economy. After the crisis of the 1990s industry recuperated slower than the rest of the economy, undergoing changes in its structure and functions" (Treyvish 2009: 49).

The greatest share of production in the USSR was made in particular in Russian enterprises. However, in the 1990s the role of new Russia in world industry declined essentially. The production of many sectors of domestic industry is no longer competitive in the world market nowadays (except raw-material industries). And today's Russia is in fact no longer among economically advanced states by macroeconomic indicators (it is referred to as a country with a "transition economy", with "emerging markets", etc.).

The share of Russia in the period 2000-2008 was only $2-3 \%$ of the world gross domestic product. During the reorganisation of its economy 'from the plan to the market', the volumes of Russian GDP and industrial output fell almost by half in comparison with the mid-1990s (Rodionova 2010). In terms of economic power (measured as
GDP at purchasing power parity), in 1996 Russia lagged behind the USA, Japan, China and four major European countries (Germany, France, Italy and Great Britain). Its per capita GDP was 6-7 thousand dollars - a quarter of the American figure, a third of the Italian, and a half of the Greek one (Treyvish 2000). The country's share in the world production of some branches of the economy was undergoing a reduction during all those years (especially in comparison with the USA, which also has conceded superiority in many manufacturing industries to a new leader - China), keeping high rates only in the extracting branches of the fuel and energy complex (Table 2).

Before the world financial and economic crisis, in the 2000s Russia's economy again showed steady, high growth rates. All basic macroeconomic indicators had improved: gross domestic product rose by an average of more than $6 \%$ per annum, inflation dropped by $10 \%$, incomes of the population and enterprises increased, and investment grew. However, the quality and stability of this growth, mainly based on a boom for raw materials in the world markets in recent years, were a cause for anxiety (Russian industry ... 2007). But this period favourable to the Russian economy ended by mid-2008 when the world financial and economic crisis began. Nowadays the questions appearing on the agenda again are an analysis of factors giving the Russian economy a competitive advantage and how to manage competitiveness by industrial policy methods to effect a transition to an innovative stage of development.

So, as many researchers observe, Russia has become an economically medium-devel- 
Table 2. Russia's and the USA's share of the world industry production, 1990-2008 (\%).

\begin{tabular}{|l|r|r|r|r|r|r|}
\hline \multirow{2}{*}{ Product } & \multicolumn{3}{|c|}{ Russia (\%) } & \multicolumn{3}{c|}{ USA (\%) } \\
\cline { 2 - 7 } & $\mathbf{1 9 9 0}$ & $\mathbf{2 0 0 0}$ & $\mathbf{2 0 0 8}$ & $\mathbf{1 9 9 0}$ & $\mathbf{2 0 0 0}$ & $\mathbf{2 0 0 8}$ \\
\hline Energy & 9.0 & 6.0 & 5.0 & 26.0 & 27.0 & 22.0 \\
\hline Oil & 17.0 & 9.0 & 12.4 & 13.0 & 10.0 & 7.8 \\
\hline Natural gas & 31.0 & 23.0 & 19.6 & 24.0 & 23.0 & 19.3 \\
\hline Coal & 8.0 & 5.0 & 4.6 & 24.0 & 27.0 & 18.0 \\
\hline Pig iron & 11.0 & 7.0 & 5.2 & 9.0 & 8.0 & 3.9 \\
\hline Steel & 12.0 & 7.0 & 5.2 & 12.0 & 12.0 & 6.9 \\
\hline Aluminium & 15.0 & 13.0 & 10.6 & 21.0 & 15.0 & 6.6 \\
\hline Mineral fertilisers & 10.0 & 6.0 & 9.5 & 16.0 & 17.0 & 12.0 \\
\hline Chemical fibres & 3.5 & 2.0 & 0.5 & 20.0 & 13.0 & 7.9 \\
\hline Cars & 3.0 & 2.0 & 2.0 & 16.0 & 14.0 & 12.3 \\
\hline Cement & 7.0 & 2.0 & 2.1 & 6.0 & & 5.0 \\
\hline
\end{tabular}

Source: calculated by the authors.

oped country of the world semi-outskirts with a number of its own problems, including those connected with the scale of the territory, a search for identity, and a place in the world economy. Nevertheless, by GDP at PPP the country is in the group of leaders, though lagging behind by GDP per capita, and having about the same share in the world gross domestic product as Great Britain and France, considerably smaller in population terms, and the developing Brazil (Table 3).

In totally reconstructing its economic mechanism in the conditions of a market economy, the country has completely lost some industrial branches. Russia nowadays depends on the world prices of fuel and other raw materials and semi-finished products as these goods account for more than $60 \%$ of its exports. In the 1990s its industrial production was reduced by almost a half (with the lowest indicator in $1998-46 \%$ of the 1990 level). In heavy engineering and chemistry the recession was even deeper (more than $70 \%$ ), not to speak of the light industry (by $1998-11 \%$, and in the 2000s its output was a mere $15 \%$ of the 1990 figure). The least loss (compared with other industrial branches) was incurred by power engineering and metallurgy. The innovative potential of industry decreased steadily. The share of innovative and active enterprises dropped from $65-70 \%$ at the end of the 1980 s to $6 \%$ by the end of 1990 . The relative volume of innovative production in total production shipped was also considerably reduced. The coefficient of fixed capital renewal in industry declined, the degree of depreciation of fixed capital reaching almost $46 \%$ in 2008 (as against $25.7 \%$ in 1970), while in some branches it even exceeded $80 \%$ (Russia in figures 2009, Socio-economic position ... 2009, Regions of Russia 2009).

Table 3. Indicators of development of the largest economies of the world, 2009.

\begin{tabular}{|c|c|c|c|c|c|c|}
\hline \multirow{2}{*}{ Countries } & \multirow{2}{*}{$\begin{array}{c}\text { GDP at PPP, } \\
\text { billion US } \\
\text { dollars }\end{array}$} & \multirow{2}{*}{$\begin{array}{c}\text { Share in } \\
\text { world GDP, } \\
\%\end{array}$} & \multirow{2}{*}{$\begin{array}{c}\text { GDP } \\
\text { per capita, } \\
\text { dollars }\end{array}$} & \multicolumn{3}{|c|}{ GDP structure, $\%$} \\
\hline & & & & agriculture & industry & services \\
\hline USA & 14,260 & 20.3 & 46,400 & 1.2 & 21.9 & 76.9 \\
\hline China (excluding Hong Kong) & 8,767 & 12.5 & 6,500 & 10.9 & 48.6 & 40.5 \\
\hline Japan & 4,141 & 5.9 & 32,600 & 1.6 & 23.1 & 75.4 \\
\hline India & 3,548 & 5.1 & 3,100 & 17.5 & 20.0 & 62.6 \\
\hline Germany & 2,812 & 4.0 & 34,200 & 0.9 & 27.1 & 72.0 \\
\hline Great Britain & 2,165 & 3.1 & 35,400 & 1.2 & 23.8 & 75.0 \\
\hline France & 2,113 & 3.0 & 32,700 & 2.1 & 19.0 & 78.9 \\
\hline Russia & 2,103 & 3.0 & 15,200 & 5.2 & 37.0 & 57.9 \\
\hline Brazil & 2,024 & 2.9 & 10,200 & 6.5 & 25.8 & 67.7 \\
\hline Italy & 1,756 & 2.5 & 30,200 & 2.1 & 25.0 & 72.9 \\
\hline World, total & 70,210 & 100.0 & 10,500 & 6.0 & 30.6 & 63.4 \\
\hline
\end{tabular}

Source: calculated on the basis of http:/ / www.cia.gov - The World Factbook. 
Despite the growth in manufacturing industries of the Russian Federation between 1999 and 2008, the output in most of them did not reach the 1990 level. Their growth rates essentially lagged behind those of the economy as a whole (except for ferrous metallurgy), and the share of manufacturing in the industrial structure kept declining throughout that period. On the whole, during 1999-2008 the GDP growth was 93.8\%, and that of the industries, $79 \%$. As a result, by 2008 the country's gross domestic product was $107 \%$ of the 1989 level, and industrial production, 85\% (Socio-economic position ... 2009).

In other words, the economy and industry of Russia have not recovered yet, and in the conditions of the present world financial and economic crisis its GDP and industrial production volume have declined again. As a result, in terms of output Russian industry has been reduced at least to the 2005 level (Institute of Economic Analysis ... 2009). And the crisis in the world economy can last some more years (which also applies to the Russian economy as part of the world system); its overcoming will not be easy.

\section{Changes in Russia's foreign trade}

For many decades (during the Soviet period) the country's economy was, in fact, artificially isolated from the world market and international competition. One of the priority issues of the economic transformation in modern Russia was the liberalisation of foreign trade, which was intended to promote deeper integration of the Russian economy with the world system.

In the years of reform, radical changes have occurred not only in the structure of Russia's gross domestic product and industry, but also in the commodity and geographical structures of its foreign trade (Table 4).

Today the geography of foreign trade operations of the Russian Federation is rather extensive. Trade is carried out with almost all countries of the world. But priorities have changed sharply. Thus, the share of the countries of 'near abroad' (the CIS states) in the foreign trade of Russia (only $14.3 \%$ in 2009) continues to decline. Note that in 1990 this indicator was 63\%. Individual economic development of the republics of the former USSR for many decades promoted a deep interconnectedness of their economic systems and a high level of integration. While in 1988-1990 about a quarter of GDP was involved in inter-republican goods turnover (within the borders of the USSR), now this indicator has decreased to one-tenth. At present the main trading partners of Russia are the 'far abroad' states and, first of all, the countries of Europe (more than 50\%) (Rodionova 2008).

The commodity structure of Russian export and import has also changed essentially. Now almost two-thirds of exports consist of fuel and raw materials (with the greatest contribution of only two goods in it: crude oil and natural gas). In our opinion, the abundance of the domestic resource base should not justify the fact that the share of finished industrial products in the country's export has fallen over the recent years (in 1975 - 33\%; 1980 - about 25\%; 1990 - about $26 \%$, and in the 2000s - less than 20\%) (Shishkov 2002: 425). By comparison, the proportion of industrial products in the export of the EU and NAFTA countries is about $80 \%$. Russia is among the world leaders in the export of natural gas, oil and mineral oil, rough diamonds, steel, aluminium, nickel, mineral fertilisers, rolled ferrous metals, and electric power. In the structure of the

Table 4. Foreign trade turnover of Russia (in balance-of-payments terms) and its geographical structure, 1994-2009.

\begin{tabular}{|l|c|c|c|c|c|c|c|c|c|}
\hline & $\mathbf{1 9 9 4}$ & $\mathbf{1 9 9 7}$ & $\mathbf{1 9 9 9}$ & $\mathbf{2 0 0 0}$ & $\mathbf{2 0 0 5}$ & $\mathbf{2 0 0 6}$ & $\mathbf{2 0 0 7}$ & $\mathbf{2 0 0 8}$ & $\mathbf{2 0 0 9 *}$ \\
\hline Total, billion US dollars & 117.8 & 158.9 & 115.1 & 149.9 & 368.9 & 468.6 & 577.9 & 763.5 & 496.0 \\
\hline \multicolumn{8}{|c|}{ By country group, \% } \\
\hline CIS countries** & 25.2 & 23.7 & 19.4 & 18.5 & 15.0 & 14.5 & 14.8 & 14.4 & 14.3 \\
\hline 'far abroad' countries & 74.8 & 76.3 & 80.6 & 81.5 & 85.0 & 85.5 & 85.2 & 85.6 & 85.7 \\
\hline
\end{tabular}

* 2009 - estimate

** CIS - Commonwealth of Independent States

Source: calculated on the basis of http://www.economy.gov.ru 
Russian export in 2005-2008, according to the data of the Federal State Statistics Service, the share of mineral products was $64-66 \%$, semi-finished products (ferrous and non-ferrous metals) and jewels $-16-17 \%$, products of the chemical industry (basically mineral fertilisers) $-5-6 \%$, and machines, equipment and transport vehicles - less than 6\% (Russia in figures 2009).

The relative share of crude oil in the total volume of Russian exports is approximately 33\%, and in the export of fuel and energy goods - over $50 \%$. In the 2000s Russia gained a maximum of advantages from the high world prices of hydrocarbon raw materials. So, over $50 \%$ of crude oil extracted in the country is being exported. But experts differ in their estimations of the influence of oil prices on the Russian economy. An extra 10 dollars of increase in the price of an oil barrel raises the Russian GDP approximately by $3-4 \%$. A fall in the prices on the world market also threatens the economic growth and development of Russia, as has occurred in the present economic crisis (Rodionova 2009).

However, the shift of the commodity structure of foreign trade towards the export of raw materials has not occurred in the recent years. Some economists consider that the deindustrialisation of Russian exports had actually acquired a "scandalous" scale before the USSR collapse. Thus, for example, the export of machines and equipment from Russia to the 'far abroad' countries dropped 6 times in value by the beginning of the 1990s, and its share in the aggregate export of the country decreased to $10.2 \%$ by 1991 , as against $35.8 \%$ several years earlier (El'yanov 1996: 52). Nowadays mechanical engineering production occupies an even more modest place in the modern structure of the Russian exports (Table 5).

An analysis of the data in Table 5 shows that the export of the production of Russia's fuel and energy sector can be observed to have grown in recent years (in terms of both, volume and value). At the same time there was an increase from $\$ 11.3$ to 151.7 billion in the export of crude oil over the analysed period (today it accounts for one-third of the Russian exports). And the volume of export of machines, equipment and transport vehicles, in comparison with the volume of export of crude oil, was $70.8 \%$ in 1995 , as against a mere $14.6 \%$ today. A sharp shift in the commodity structure of the Russian exports towards raw materials is evident. These figures call for profound analysis. Certainly, the export of engineering production from 1995 to 2008 increased (in terms of value) too, more than 2.6 times, but at the same time its share in total exports dropped by approximately a half. The main increase in the export of the production of this industry is due to the CIS countries.

Once again let us underline that today products of the extracting industry prevail in the export of the Russian Federation. At the same time the share of the products of the fuel and energy sector (oil, natural gas, coal) and oil products is only $65 \%$. This means that Russia's role as a socalled 'raw-material appendage' of developed countries is increasing, despite the state policy aimed at boosting the overall effectiveness of the

Table 5. Change in the export structure of the Russian Federation, 1995-2008.

\begin{tabular}{|c|c|c|c|c|c|c|c|c|}
\hline \multirow{2}{*}{ Export by product } & \multicolumn{8}{|c|}{ Years } \\
\hline & 1995 & 2000 & 2001 & 2002 & 2003 & 2004 & 2005 & 2008 \\
\hline \multicolumn{9}{|c|}{ At current prices, billion US dollars } \\
\hline Export, total & 78.2 & 103.1 & 100.0 & 106.7 & 133.7 & 181.7 & 241.5 & 468.1 \\
\hline Machinery and equipment & 8.0 & 9.1 & 10.5 & 10.1 & 12.0 & 14.1 & 13.5 & 22.1 \\
\hline Crude oil & 11.3 & 25.4 & 24.5 & 29.0 & 38.8 & 58.3 & 83.5 & 151.7 \\
\hline Refined petroleum (oil products) & 4.9 & 10.9 & 9.4 & 11.2 & 14.1 & 19.3 & 37.3 & 78.3 \\
\hline Natural gas & 11.4 & 16.7 & 18.3 & 15.9 & 20.0 & 21.8 & 31.3 & 66.4 \\
\hline \multicolumn{9}{|c|}{ Export of crude oil, in $\%$ of the total } \\
\hline Crude oil & 14.5 & 24.6 & 24.5 & 27.2 & 29.0 & 32.1 & 34.6 & 32.4 \\
\hline \multicolumn{9}{|c|}{ Export of machinery and equipment, in $\%$ of the total } \\
\hline Machinery and equipment & 10.2 & 8.8 & 10.5 & 9.5 & 9.0 & 7.8 & 5.6 & 4.7 \\
\hline \multicolumn{9}{|c|}{ Volume of export of machinery and equipment in comparison with that of crude oil, in \% } \\
\hline & 70.8 & 35.9 & 42.9 & 34.9 & 30.9 & 24.2 & 16.2 & 14.6 \\
\hline
\end{tabular}

Source: calculated on the basis of the Russian Statistical Yearbook 2007-2009 and the Federal Customs Agency ... (2008). 
Table 6. External trade of the Russian Federation (in balance-of-payments terms), in billion dollars.

\begin{tabular}{|c|c|c|c|c|c|c|}
\hline & \multicolumn{3}{|c|}{2008} & \multicolumn{3}{|c|}{2009 (estimate) } \\
\hline & \multirow[b]{2}{*}{ Total } & \multicolumn{2}{|c|}{ of which: } & \multirow[b]{2}{*}{ Total } & \multicolumn{2}{|c|}{ of which: } \\
\hline & & $\begin{array}{l}\text { with 'far } \\
\text { abroad' } \\
\text { countries }\end{array}$ & $\begin{array}{l}\text { with CIS } \\
\text { countries }\end{array}$ & & $\begin{array}{l}\text { with 'far } \\
\text { abroad' } \\
\text { countries }\end{array}$ & $\begin{array}{l}\text { with CIS } \\
\text { countries }\end{array}$ \\
\hline External trade turnover & 763.5 & 653.4 & 110.1 & 496.0 & 423.0 & 73.0 \\
\hline Export & 471.6 & 400.5 & 71.1 & 303.3 & 255.2 & 48.1 \\
\hline Import & 291.9 & 252.9 & 39.0 & 192.7 & 167.8 & 24.9 \\
\hline Trade balance & 179.7 & 147.5 & 32.2 & 110.6 & 87.4 & 23.2 \\
\hline
\end{tabular}

Source: calculated on the basis of On the results ... (2010).

engineering industry branch and the growth of competitiveness of its production.

Besides, the volume of imported engineering production considerably exceeds its export. According to Rosstat and the Federal Customs Service, in 2008 the export of the engineering industry amounted to $\$ 22.1$ billion, or $4.7 \%$ of total exports. The import of the Russian Federation amounted to $\$ 266.9$ billion, of which $\$ 170.9$ billion were contributed by the engineering industry, that is, $64.5 \%$ of the total amount of imported goods (mostly from the 'far abroad' countries) (Socio-economic position... 2009). In other words, the import of engineering production exceeds its export almost 8 times, which testifies to the prevalence of foreign manufacturers on the Russian commodity market. The share of Russian import grew, while the volumes of industrial output kept decreasing. Russia's demand for the production of the chemical industry and hightech equipment, and also for basic foodstuffs and pharmaceutical products, is satisfied today by deliveries from the EU and other countries to a substantial extent.

In the conditions of the global crisis of the world economy, in 2009 there was a considerable decrease in the volume of Russia's foreign trade with the countries of the world in comparison with 2008 (Table 6).

At the same time the trade balance remains positive (export exceeds import 1.5 times). And as mentioned above, the exchange with the 'far abroad' countries (first of all Western Europe) predominates in foreign trade turnover (as well as in export), at $84-85 \%$.

\section{Model of Russia's participation in the globalised world}

We strongly believe that a full-scale participation of Russia in the international division of labour should undoubtedly be connected with the development of the industrial sector of its economy and with a diversification and improvement of its export structure. The task of boosting the competitiveness of Russian industry (which demands a more detailed research) and of changing the role of the country in manufacturing and the distribution of the world income demands a well-thought-out approach focused on revealing new 'niches' of international manufacturing and economic exchange.

In concluding this brief review of the current state of the Russian economy, let us stress that the majority of economically advanced countries have already moved from traditional industrial production to high-tech production, designing the latest information technology, and high-tech development of services. The export of information-communication technologies from the country keeps growing, but by key indicators in this sphere, Russia is still far behind the developed countries of the world. For example, by the Networked Readiness Index ${ }^{2}$, Russia is only in the 72nd place (out of 122) in the international ranking, which proves that the country is not completely ready to use modern scientific achieve-

2 The World Economic Forum publishes rankings by the index of the development of information and communication technology in different world countries (Networked Readiness Index, NRI). It takes into account the level of the ICT market, its influence on and penetration into other spheres, as well as the success of government policy aimed at the intensification of ICT use (Global Information 2008-2009). 
ments and information-telecommunication technologies in the economy and other spheres of the population's life.

In the long term, an increase in the competitiveness of Russian goods will demand a considerable rise in the efficiency of using the domestic resource base, which in turn involves a radical modernisation of the industrial sector, a change in the assortment of goods produced, and an improvement in their qualitative characteristics. In other words, a cardinal modernisation of manufacturing will demand considerable investment. However, with the present level of profitability of the majority of Russian manufacturing enterprises $(17 \%, 2008)$, they cannot be attractive objects to external investors, and the capital of those enterprises is insufficient to solve the large-scale targets of modernisation.

In our opinion, Russia should find its own niche in the world economy and the world market, and especially in the knowledge-intensive and high-technology branches. Russia's President Dmitry Medvedev continually takes up this subject in his speeches, declaring that the preservation and development of the country's scientific and technical potential should become one of the main priorities of state economic policy.

Contrary to optimistic predictions, according to the present authors, in countries with an 'under-modernised' economy (i.e. in which transformation processes in the economy have not finished yet), including Russia, the current world financial and economic crisis threatens with a prolonged period of depression and recession (unlike the previous crisis of 1998). In 2009
Russia's GDP already contracted more considerably than the world figure.

It is also necessary to highlight one more aspect of the problem of Russia's place in the world manufacturing industry and in the manufacture and export of high-tech production. An analysis of data presented in the report Science and Engineering Indicators (2010) shows Russia to lag badly behind the world leaders, even though it is among the top ten largest industrial powers of the world (Table 7).

At the same time Russia is not among the leaders of world high-tech production. Technological achievements (scientific and technical progress) are the key factor determining growth in labour productivity and international competitiveness. However, in the analysis of productivity of manufacturing and structural changes, technological criteria play a significant role. To define such criteria, use has been made of a methodological research by the OECD. At present the OECD defines the following five high-tech branches characterised by the highest $R \& D$ intensity: aerospace; computer facilities manufacture - computers/office machinery; manufacture of a communication facility - communication equipment; manufacture of high-precision scientific and medical equipment (scientific instruments); and the pharmaceutical industry (Science and Engineering Indicators, 2008).

The knowledge-intensive branches and high technologies are in the vanguard of economic development today. The basic part of $R \& D$ results materialises in them; they determine the demand for achievements of science and create a basis for

Table 7. Changes in the share of the leading countries in the world value added of all manufacturing industries in 1985-2007 (\%).

\begin{tabular}{|c|l|r|r|r|r|r|r|}
\hline \multicolumn{1}{|c|}{ Country } & $\mathbf{1 9 8 5}$ & $\mathbf{1 9 9 0}$ & $\mathbf{1 9 9 5}$ & $\mathbf{2 0 0 0}$ & $\mathbf{2 0 0 5}$ & $\mathbf{2 0 0 7}$ \\
\hline 1 & USA & 31.0 & 23.2 & 22.3 & 27.2 & 22.4 & 19.8 \\
\hline 2 & China (including Hong Kong) & 4.6 & 3.3 & 4.6 & 7.0 & 10.2 & 14.3 \\
\hline 3 & Japan & 15.3 & 18.9 & 21.9 & 18.3 & 13.5 & 10.1 \\
\hline 4 & Germany & 8.4 & 10.5 & 9.3 & 6.9 & 7.9 & 8.0 \\
\hline 5 & Italy & 4.1 & 5.6 & 4.0 & 3.6 & 4.1 & 3.9 \\
\hline 6 & Great Britain & 4.0 & 4.8 & 3.9 & 4.0 & 3.7 & 3.6 \\
\hline 7 & France & 0.9 & 4.8 & 4.2 & 3.4 & 3.5 & 3.2 \\
\hline 8 & South Korea & 0.3 & 1.5 & 2.3 & 2.4 & 2.8 & 2.7 \\
\hline 9 & Russia & 2.7 & 2.2 & 0.9 & 0.8 & 1.7 & 2.3 \\
\hline 10 & Brazil & & 2.2 & 1.7 & 1.9 & 2.3 \\
\hline
\end{tabular}

Source: calculated on the basis of Science and Engineering Indicators (2010), Appendix Tables 6-18.

Note: All original data given at current prices in US dollars. 
Table 8. Value added of high-technology manufacturing industries, by leading countries: 1985-2007

(\% of the world figure).

\begin{tabular}{|c|l|r|r|r|r|r|c|}
\hline \multicolumn{1}{|c|}{ Country } & $\mathbf{1 9 8 5}$ & $\mathbf{1 9 9 0}$ & $\mathbf{1 9 9 5}$ & $\mathbf{2 0 0 0}$ & $\mathbf{2 0 0 5}$ & $\mathbf{2 0 0 7}$ \\
\hline 1 & USA & 42.3 & 31.2 & 29.1 & 34.5 & 29.8 & 30.7 \\
\hline 2 & China (including Hong Kong) & 3.1 & 2.3 & 2.6 & 4.1 & 10.0 & 13.7 \\
\hline 3 & Japan & 18.5 & 23.6 & 26.8 & 21.4 & 15.0 & 10.6 \\
\hline 4 & Germany & 7.8 & 8.0 & 6.4 & 5.1 & 6.9 & 7.0 \\
\hline 5 & South Korea & 0.9 & 1.8 & 3.5 & 3.8 & 4.8 & 4.7 \\
\hline 6 & Great Britain & 4.4 & 5.7 & 4.5 & 4.6 & 4.4 & 4.3 \\
\hline 7 & France & 3.8 & 4.5 & 4.3 & 3.6 & 3.6 & 3.5 \\
\hline 8 & Italy & 3.1 & 4.5 & 2.6 & 2.2 & 2.6 & 2.5 \\
\hline 9 & Taiwan & 0.7 & 1.2 & 1.7 & 2.7 & 2.5 & 2.0 \\
\hline 10 & Brazil & 2.0 & 1.9 & 1.8 & 1.5 & 1.4 & 1.6 \\
\hline
\end{tabular}

Source: calculated on the basis of Science and Engineering Indicators (2010), Appendix Tables 6-5.

Note: All original data given at current prices in US dollars.

material and information innovations in practically all the branches of the economy. The level of the high-tech sector and the scale of use of high technologies characterise the scientific-technological and economic potential of a country. The advanced countries headed by the USA (Table 8) are leaders in this sphere.

But an analysis of the data presented in the table shows that considerable progress is in the group of developing countries (South Korea, Taiwan, Brazil), and especially in China. The share of this country in the world high-tech production (and in the world export) grows at unprecedentedly high rates, while in Russia such growth has not been observed in recent years. Even compared with the key developing BRIC countries (Brazil, Russia, India, China), Russia's total share in the world high-tech production does not look impressive (Table 9).

The EU and NAFTA contributions are stable as the countries entering into those economic unions are leaders of the world economy. The proportion of high technology and high-tech goods in the industry of the majority of advanced countries increases, and as a result their industrial structure changes. The development of high technologies also leads to rapid changes in the character of goods transported, i.e. changes in the commodity structure of the world market reflecting priorities of the scientific and technical policies of the various countries. So there is a very interesting picture of change in the positions of countries and regions leading in hightech exports (Table 10).

The EU still holds the leading position in the world trade ranking (especially taking into account intra-regional trade). But among the world countries, China has become the leader in the export of high-tech goods $(21.4 \%$ in 2008). At the same time (even excluding domestic trade between China and Hong Kong) the share of China in the world 2008 index was over 15\%, equal

Table 9. Dynamics of the share of countries (BRIC) and country groups in the world value added of high-tech manufacturing industries, 1985-2007 (\%).

\begin{tabular}{|l|r|r|r|r|r|r|r|}
\hline \multicolumn{1}{|c|}{ Country and country groups } & $\mathbf{1 9 8 5}$ & $\mathbf{1 9 9 0}$ & $\mathbf{1 9 9 5}$ & $\mathbf{2 0 0 0}$ & $\mathbf{2 0 0 5}$ & $\mathbf{2 0 0 7}$ \\
\hline Brazil & 2.0 & 1.9 & 1.8 & 1.5 & 1.4 & 1.6 \\
\hline Russia & 0.1 & 0.1 & 0.5 & 0.2 & 0.6 & 0.8 \\
\hline India & 0.3 & 0.3 & 0.4 & 0.3 & 0.6 & 0.7 \\
\hline China (including Hong Kong) & 3.1 & 2.3 & 2.6 & 4.1 & 10.0 & 13.7 \\
\hline \multicolumn{7}{|c|}{ By comparison: } & \\
\hline EU & 24.3 & 29.2 & 24.2 & 21.6 & 25.3 & 25.1 \\
\hline NAFTA (USA, Canada, Mexico) & 44.9 & 33.7 & 31.2 & 37.8 & 32.8 & 33.5 \\
\hline
\end{tabular}

Source: calculated on the basis of Science and Engineering Indicators (2010), Appendix Tables 6-5.

Note: All original data given at current prices in US dollars. 
Table 10. Exports and imports of high-technology goods, by region / country / economy: 1995-2008 (\%).

\begin{tabular}{|c|c|c|c|c|}
\hline Region / country / economy & 1995 & 2000 & 2005 & 2008 \\
\hline World & 100.0 & 100.0 & 100.0 & 100.0 \\
\hline World excluding intra-EU and intra-China/Hong Kong & 80.0 & 80.1 & 77.7 & 78.4 \\
\hline EU (total) & 31.1 & 20.0 & 31.0 & 29.3 \\
\hline Intra-EU & 18.0 & 17.5 & 16.9 & 15.7 \\
\hline EU - ROW* & 13.1 & 12.5 & 14.1 & 13.6 \\
\hline China and Hong Kong total & 6.9 & 8.5 & 18.2 & 21.4 \\
\hline China and Hong Kong - ROW* & 5.0 & 6.0 & 12.9 & 15.6 \\
\hline USA & 17.0 & 17.2 & 11.5 & 10.7 \\
\hline Japan & 14.7 & 10.4 & 7.1 & 6.4 \\
\hline
\end{tabular}

*ROW $=$ Rest of World

Source: calculated on the basis of Science and Engineering Indicators (2010), Appendix Tables 6.

Note: All original data given at current prices in US dollars.

to the share of inter-regional trade of all the 27 European Union states. China has already outstripped the USA and Japan. Worth considering is the fact that this country's growth rates have not decreased so strongly, even in the conditions of the present world crisis and despite the situation in Russia, which is not among the leaders of trade in high-tech products.

\section{Conclusion}

However, the present world financial and economic crisis can be considered a certain new opportunity for the development of Russia (as another turning point in its history). The situation can evolve in two ways: either Russia will switch to an innovative and technological model of development, or it will roll down to the world outskirts, as a raw-material appendage of advanced countries. In this connection it is necessary to recollect the destructive influence of globalisation on the Russian economy. The requirements of the world market greatly favour a transformation of its national economy into an exportoriented energy and raw-material segment of the global economy.

At the same time in modern Russia the simple use of the intellectual, technical, scientific and technological capabilities of the previous years without growth and development dooms its industry and economy to an inevitable and growing lag. This is happening against a back- ground of accelerated practical application of scientific knowledge embodied in innovation and reinforcement of the scientific and technological capabilities of many countries, not only those advanced economically.

The execution of industrial and innovative policies in Russia should be directed at a continuous integration of its economy primarily with the high-tech framework of the world global economic environment.

The authors of the article strongly believe that the systemic transformation and structural reorganisation of Russia's economy should undoubtedly be directed towards changing the country's present position in the system of world economic links within the basic postindustrial tendencies.

\section{References}

Central Bank of the Russian Federation, 2010. http:/ / cbr.ru

EL'YANOV A.Y., 1996. Russia is on the way toward the industrial civilisation: The world economic aspect. World economy and international relations 12: 48-55.

Federal Customs Agency of the foreign trade of Russia, 2008.

Global Information Technology Report, 2008-2009: Mobility in a Networked World. World Economic Forum.

Index of Economic Freedom, 2010. Heritage Foundation \& The Wall Street Journal, http://www.heritage.org/index/ TopTen.aspx.

Institute of Economic Analysis data based on the information of Business Environment Centre under the Russian government, 2009. http:/ / www.aillarionov.livejournal.com.

International Monetary Fund, http://www.imf.org/external/index.htm. 
Knowledge Economy Index, World Bank, http://info.worldbank.org/etools/ kam/kei_table.asp.

Ministry of Economy of Russia, http://www.economy.gov. ru.

On the results of social and economic development of the Russian Federation in 2009. Report of the Ministry of Economic Development and Trade of the Russian Federation (February 2010), http://www.economy.gov.ru/minec/main.

Regions of Russia, 1998-2009. Federal State Statistics Service (Rosstat), Moscow.

Rodionova I. (ed.), 2008. Economic, social and political geography: World, regions, countries. Econ-Inform, Moscow.

RoDionova I., 2009. World industry: Structural shifts and the tendencies of development (the second part of the $20^{\text {th }}$ - the beginning of the $21^{\text {st }}$ century). GOU VPO MGUL, Moscow.

Rodionova I., 2010. World economy: The industrial sector. PFUR, Moscow.

Russia in figures, 2009. Brief statistical review. Short statistical book, Federal State Statistics Service (Rosstat), Moscow.

Russian industry at the crossroads. What prevents our companies from becoming competitive. Report of the SU-HSE about the competitiveness of Russian manufacturing industry, 2007: Publishing House of the SU-HSE, Moscow.
Russian Statistical Yearbook, 2007-2009. Federal State Statistics Service (Rosstat), Moscow.

Science and Engineering Indicators, 2010. Appendix Tables 6. Two volumes. Arlington, VA: National Science Foundation, http://www.nsf.gov

SHishrov Y.V., 2002. The period of the half-collapse of the CIS has finished. What is ahead? The Security of Eurasia 1(7): 125-134.

Socio-economic position of Russia, 1998-2009. Statistical book, Federal State Statistics Service (Rosstat), Moscow.

Strategic directions of the economic development of Russia, 2010. Scientific report. Alteya, St. Petersburg.

TREYVISH A., 2009. Russian industry in post-industrial surroundings. In: Rodionova I. (ed.), Changes in the spatial organisation of world industry: The second part of the 20th century - the beginning of the 21st century. Econ-Inform, Moscow.

Treyvish A., 2000. Soviet and Russian economy against the world background. Geography 7: 1-3.

World Economic Outlook. Crisis and recovery, 2009. International Monetary Fund, World Economic and Financial Surveys. Washington, D.C., http:/ / www.imf.org.

World Factbook. http://www.cia.gov 